INTERNATIONAL BULLETIN OF BACTERIOLOGICAL
NOMENCLATURE AND TAXONOMY
$\begin{array}{llll}\text { Volume } 11 & \text { No. } 3 & \text { July } 15,1961 & \text { pp. 99-100 }\end{array}$

\title{
THE DEFINITION OF PHAGE TYPES OF SALMONELLA PARATYPHI B
}

\author{
Dr. R. Th. Scholtens \\ National Institute of Public Health \\ Utrecht, Netherlands
}

SUMMARY: A phage type is defined as a collection of bacterial strains with the same phage relationships. Satisfactory type definitions have been developed for Salmonella typhi. Definition for type definitions for

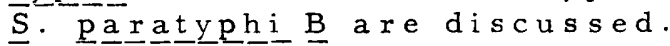

Phage typing results in a varietal subdivision of Salmonella (species, Kauffmann 1959) into phage types.

A phage type is a collection of bacterial strains with the same phage relationships.

Before taxonomy of types can be discussed a definition of type is necessary. The application of this type definition should give rise to a systematic arrangement of types, if possible. The conditions which a collection of bacterial strains must satisfy if such collection is to be recognized as a phage type must be a guarantee of the homogeniety of the collection. These conditions must be satisfied objectively and must be reproducable.

Such a type definition results for Salmonella typhi. A new type is being determined by and adaptation of a Vi phage, and, as far as possible by an adaptation of a phage Vi II of Craigie and Yeh (1938). The homogeneity of the phage types was confirmed by an examination of the lysogenic properties.

The relationship is different with $\underline{S}$. paratyphi $B$. A similar type definition is not given in the system of Felix and Callow (1951). The role of the adaptations of phage 1 of Felix and Callow is different from that of phage Vi II in the system of Craigie and Yen. It has appeared that the adaptations of phage 1 of Felix and Callow indicated groups of types (Scholtens, 1955). These groups can be subdivided with specific phage reactions into types as is done in the natural system of phage types of Salmonella paratyphi $\underline{B}$ (Scholtens, 1956, 1959).

With the natural system of "phage types" a type defini- 
tion results for the phage types of Salmonella paratyphi $B$; all bacterial strains of a natural phage type possess the same phage sensitivities besides the same lysogenic properties (Scholtens, 1952). The homogeneity of one of the group of properties is a guarantee of homogeneity as regards the other. This type definition results in a systematic arrangement of types (Scholtens, 1956). It covers all the phage relationships (properties) of the bacterial strains. It agrees with the International Code of Nomenclature of the Bacteria and Viruses that recognized the individual microörganism as a unit.

\section{LITERAT URE}

Craigie, J.A. and C.H. Yen. 1938. Can. Publ. Hlth.

Jour. 29: 448 .

Felix, A. and B.R. Callow. 1951. The Lancet, II, 3.

Kauffmann, F. 1959. Internatl. Bull. Bact. Nomen. and Taxon. 9:1

Scholtens, R. Th. 1952. Ant. v. Leeuwenhoek. 18: 257. - 1956. Ant. v. Leeuwenhoek. 22: 65 .

. 1959. Ant. v. Leeuwenhoek. $25: 403$. 